\title{
PENGARUH INVESTASI HUMAN CAPITAL IKLIM ORGANISASI TERHADAP KINERJA KAYAWAN DAN DAMPAKNYA TERHADAP KINERJA ORGANISASI PENGELOLAAN HUTAN PRODUKSI SECARA LESTARI (KINERJA PHPL) PT. KALIMANTAN SATYA KENCANA (PT. KSK)
}

\author{
Nandang Supriantna, Sugito Efendi dan Edi Sugiono \\ Alumni Univertias Nasional/Praktisi Bisnis \\ ndg_s@yahoo.co.id
}

\begin{abstract}
Abstrak. Tujuan dari penelitian ini adalah untuk menganalisis seberapa besar pengaruh investasi human capital, iklim organsasi tehadap kinerja karyawan dan dampaknya terhadap kinerja PHPL baik secara parsial maupun secara simultan. Studi penelitian ini dilakukan terhadap karyawan PT. Kalimantan Satya Kencana (PT. KSK) di Kalimantan Barat. PT. KSK adalah perusahaan yang bergerak di bidang pengelolan kehutanan. Data yang digunakan adalah data primer, dengan cara melakukan wawancara langsung dan mengisi data kuesioner terhadap 58 karyawan. Adapun metode analisis yang digunakan adalah Analisis Jalur (Path Analysis) dan diolah dengan software SPSS 17. Hasil analisis menunjukkan bahwa secara signifikan dan simultan investasi human capital dan iklim organisasi berpengaruh searah (positif) terhadap kinerja karyawan dengan hasil koefisien determinasi $\left(\mathrm{R}^{2}\right)$ sebesar $17,6 \%$. Dengan metode trimming bahwa Kinerja Karyawan dan Iklim organisasi secara signifikan dan simultan berpengaruh langsung dan searah (positif) terhadap Kinerja PHPL, sedangkan investasi human capital berpengaruh secara tidak langsung terhadap kinerja PHPL dengan hasil koefisien determinasi $\left(\mathrm{R}^{2}\right)$ secara keseluruhan sebesar 44,28 \%. Temuan tersebut mengindikasikan bahwa untuk memenuhi dan meningkatkan kinerja PHPL, PT. KSK perlu memperhatikan faktor-faktor investasi human capital, iklim organisasi dan kinerja karyawan karena faktor-faktor tersebut terbukti mempengaruhi keberhasilan perolehan sertifikat kinerja PHPL.
\end{abstract}

Kata Kunci : Investasi Human Capital, Iklim Organisasi, Kinerja, Kinerja Karyawan, Kinerja PHPL dan Analisis Jalur (Path Analysis).

Abstract. The purpose of this study was to analyze how much influence human capital investment, organizational climate with employee performance and its impact on SFM either partially or simultaneously. This research study was conducted on employees of PT. Kalimantan Satya Kencana (PT. CWC) in West Kalimantan. PT. KSK is a company engaged in the management of forestry. The data used is primary data, collecting by direct interviews and filled out the questionnaire to 58 employees. The analytical method used is Path Analysis (Path Analysis) and processed with SPSS 17 software.

The analysis showed that the significant and simultaneous human capital investment and organizational climate direction (positive) on the performance of employees with the coefficient of determination $\left(R^{2}\right)$ of $17.6 \%$. With this method of trimming that employee performance and organizational climate significantly and simultaneously direct influence and direction (positive) on the Performance of SFM, while the human capital investment indirect effect on the SFM with the coefficient of determination $\left(R^{2}\right)$ as a whole amounted to $44.28 \%$. These findings indicate that in order to meet and improve SFM, PT. KSK need to pay attention to factors of human capital investment, organizational climate and employee performance because of these factors shown to affect the success of the acquisition of certificates of SFM.

Keywords : Capital Human Investation,organizational climate, employee performance, PT KSK, path analysis. 
Iklim Organisasi dan cara kerja di PT. Kalimantan Satya Kencana pada saat ini masih dikatakan belum efektif dan efisien halini dapat dilihat dari berbagai aspek diantara nya kinerja karyawan masih rendah, hal ini di tandai banyak karyawan yang belum sesuai dengan keahlian bidangnya, tingkat pendidikan dan keterampilan yang rendah, penyebab rendahnya produktifitas ini di sebab kan oleh iklim kerja di da2lam organisasi tersebut tidak terasa nyaman untuk bekerja, Suasana kerja yang tidak kondusif mempengaruhi kinerja karyawan.

Fenomena yang ada di lapangan terlihat bahwa kinerja organisasi semakin melemah, yang terlihat dari mulai menurunnya produksi, melemahnya koordinasi dan komunikasi organisasi. Fenomena tersebut secara tidak langsung disebabkan oleh lemahnya kinerja karyawan, yang ditunjukkan dengan munculnya fenomena seringnya target kerja yang tidak tercapai, karyawan seringkali mangkir atau malas bekerja, kekompakkan tim melemah dll

Kinerja organisasi/perusahaanpat sendiri dapat dilihat dari beberapa perspektif seperti perspektif konsumen, keuangan, proses pembelajaran dan pertumbuhan, anggaran, dan tujuan strategis. Kesemua aspek di atas terlihat makin melemah.

Berdasarkan pengalaman empiris bekerja pada sektor kehutanan lebih 20 tahun, faktor utama dalam keberhasilan pengelolaan hutan antara lain adalah profesionalitas sumber daya manusia yang merupakan sebagai modal (Human Capital) dan kondisi/iklim perusahaan/organisasi yang sangat memegang peranan penting dalam keberhasilan perolehan kinerja PHPL tersebut. Aspek di atas dewasa ini terlihat makin melemah.

$\begin{array}{ccc}\text { Upaya } & \text { untuk } & \text { mengembangkan } \\ \text { profesionalitas } & \text { SDM dilakukan dengan }\end{array}$ mengembangkan Investasi human capital berupa pendidikan, dan diklat pengalaman, keterampilan dan pengetahuan, diyakini sebagai faktor penentu keberhasilan/kinerja dalam berbagai organisasi. Sedangkan iklim organisasi yang merupakan persepsi anggota organisasi dan mereka yang secara tetap berhubungan dengan organisasi (misalnya pemasok, konsumen, konsultan, dan kontraktor) mengenai apa yang ada atau terjadi di lingkungan internal organisasi secara rutin, yang mempengaruhi sikap dan perilaku organisasi dan kinerja karyawan yang kemudian menentukan kinerja organisasi di PT. Kalimantan Satya Kencana (PT.KSK)

Dari uraian di atas, maka dalam penelitian ini akan dirumuskan masalah : 1) Seberapa besar pengaruh investasi human capital terhadap kinerja karyawan PT. Kalimantan Satya Kencana?, 2) Seberapa besar pengaruh iklim organisasi terhadap kinerja karyawan PT. Kalimantan Satya Kencana?, 3) Seberapa besar pengaruh investasi human capital dan iklim organisasi terhadap kinerja karyawan PT. Kalimantan Satya Kencana secara bersama-sama/simultan?, 4) Seberapa besar pengaruh investasi human capital terhadap kinerja organisasi Pengelolaan Hutan Alam Produksi secara Lestari (kinerja PHPL) PT. Kalimantan Satya Kencana?, 5) Seberapa besar pengaruh iklim organisasi terhadap kinerja organisasi Pengelolaan Hutan Alam Produksi secara Lestari (kinerja PHPL) PT. Kalimantan Satya Kencana?, 6) Seberapa besar pengaruh kinerja karyawan terhadap kinerja organisasi Pengelolaan Hutan Alam Produksi secara Lestari (kinerja PHPL) PT. Kalimantan Satya Kencana?, dan 7) Seberapa besar pengaruh investasi human capital, iklim organisasi dan kinerja karyawan terhadap kinerja organisasi Pengelolaan Hutan Alam Produksi secara Lestari (kinerja PHPL) PT. Kalimantan Satya Kencana secara bersama-sama/simultan?

Tujuan Penelitian secara umum adalah untuk menganalisis pengaruh investasi human capital dan iklim organisasi terhadap kinerja karyawan dan dampaknya terhadap kinerja organisasi Pengelolaan Hutan alam Poduksi secara Lestari (Kinerja PHPL) pada perusahaan PT. Kalimantan Satya Kencana.

Adapun kegunanaan penelitian ini adalah sebagai berikut : 1) Secara Praktis ; diharapkan dapat memberikan masukan pada perusahaan-perusahaan yang bergerak dalam sektor kehutanan untuk dapat mengetahui upaya-upaya strategis dalam rangka pencapaian pemenuhan kinerja PHPL yang diwajibkan oleh pemerintah. Sedangkan untuk instansi kehutanan diharapkan dapat dijadikan acuan/masukan dalam memberikan kebijakankebijakan terkait Pengelolaan Hutan Produksi secara Lestari di lapangan; dan 2) Secara 
Nandang Supriantna, Sugito Efendi dan Edi Sugiono, Pengaruh Investasi Human Capital Iklim..

teoritis/akademis ; diharapkan dapat memberikan manfaat dan sumbangan dalam pengembangan ilmu, khususnya ilmu manajemen sumber daya manusia dan ilmu pengelolaan hutan. Memberikan wawasan tentang kajian ilmu manajemen sumber daya manusia yang dikaitkan dengan ilmu kehutanan.

Ruang lingkup dan batasan bahasan adalah sebagai berikut : 1) Terdapat 2 (dua) variabel bebas yaitu : Investasi Human Capital dan Iklim organisasi; 1 (satu) variabel antara yaitu Kinerja Karyawan dan ; 1 (satu) variabel terikat yaitu Kinerja Organisasi dengan perspektif Pengelolan Hutan Alam Produksi secara Lestari (Kinerja PHPL), 2) Pada variable Investasi Human Capital, data yang diteliti bukan merupakan investasi langsung berupa nilai uang yang ditanamkan, tetapi meneliti data-data yang merupakan indikator-indikator yang telah dilakukan oleh perusahaan yang digali melalui kuisioner. Adapun indikatorindikator yang digunakan adalah : pendidikan dan pelatihan (Diklat), On Job training, tingkat dan latar belakang pendidikan, serta pengalaman kerja (Becker, 1975 dan Unger, et. al., 2009 dalam Tjiptono, 2011), 3) Penelitian dilakukan pada perusahaan yang bergerak dalam bidang kehutanan PT. KALIMANTAN SATYA KENCANA (PT. KSK) dengan luas areal \pm $48.000 \mathrm{Ha}$, lokasi arealnya terletak di Kabupaten Melawi Provinsi Kalimantan Barat. Pada saat ini jumlah karyawan seluruhnya adalah 138 orang, dan 4) Data dianalisis dengan menggunakan Program SPSS 17.

Davenport (2003) dalam Sandra (2008) mendefinikan Human Capital sebagai seluruh usaha yang dibawa tenaga kerja untuk diinvestasikan dalam pekerjaan mereka. Pengembangan human capital adalah sebuah bentuk investasi dan merupakan tuntutan dari ekonomi modern yang tidak bisa dihindari. Konsep investasi human capital tersebut juga berlaku pada organisasi bisnis modern saat ini dalam rangka menghadapi persaingan bisnis yang semakin ketat (Sugiono,2011). Prinsip investasi yang dilakukan pada bidang sumber daya manusia adalah mengorbankan sejumlah dana yang dikeluarkan dan kesempatan memperoleh penghasilan selama proses investasi. Dan sebagai imbalannya adalah tingkat penghasilan yang lebih tinggi untuk mampu mencapai tingkat komsumsi yang lebih tinggi juga. Investasi yang demikian dinamakan investasi human capital (Simanjuntak, 1998).

Investasi Human Capital merupakan suatu upaya untuk meningkatkan nilai tambah "barang atau jasa" yang dihasilkan di kemudian hari dengan mengorbankan kesempatan untuk menikmati konsumsi hari ini. Sesuai prinsip investasi manusia, nilai ekonomisnya dapat berkembang di kemudian hari melalui suatu proses pertambahan nilai seperti peningkatan sikap, perilaku, wawasan, kemampuan, keahlian dan keterampilan (Muhi, 2012)

Menurut Becker (1962), investasi human capital dapat dilakukan melalui cara : 1) pendidikan (schooling), 2) pelatihan baik formal maupun informal (on the job training), 3) perawatan kesehatan, dan 4) perolehan informasi tentang sistem ekonomi. Dalam perkembangan selanjutnya, menurut Becker (1975) dalam Tjiptono (2011), investasi human capital dapat dilakukan melalui : 1) pendidikan di sekolah, 2) pelatihan, 3) investasi pengetahuan spesifik perusahaan, 4) pilihan karir, dan 5) karakter-karakter lain yang berkaitan dengan pekerjaan (upah/gaji dan jam kerja). Dalam meta analisisnya terhadap 70 studi tentang hubungan human capital dengan kesuksesan bisnis, Unger, et. al. (2009) dalam Tjiptono (2011) mengidentifikasikan beberapa indikator investasi human capital diantaranya : 1) pendidikan, 2) pengalaman manajerial, dan 3) pengalaman kerja.

\section{Iklim Organisasi}

Sebuah organisasi mempunyai kecenderungan untuk mempertahankan pegawai dengan nilai-nilai individu yang sesuai dengan iklimnya (Higgins, 1982 dalam Apriyatno, 2008). Demikian pula sebaliknya, seorang pegawai akan memilih suatu organisasi dimana iklim organisasinya sesuai dengan nilai yang dianutnya (Davis, 1996 dalam Apriyatno, 2008).

Wirawan (2007) memberikan definisi iklim organisasi yang lebih luas yaitu persepsi anggota organisasi (secara individu dan kelompok) dan mereka yang secara tetap berhubungan dengan organisasi (misalnya pemasok, konsumen, konsultan, dan kontraktor) mengenai apa yang ada atau terjadi di lingkungan internal organisasi secara rutin, yang mempengaruhi sikap dan perilaku organisasi 
dan kinerja anggota organisasi yang kemudian menentukan kinerja organisasi.

Stringer (2002) dalam Wirawan (2007) menyatakan bahwa untuk mengukur iklim organisasi terdapat 6 (enam) dimensi, yaitu : 1) Struktur, 2) Standar-standar, 3) Tanggung jawab, 4) Penghargaan/pengakuan, 5) Dukungan, dan 6) Komitmen.

\section{Kinerja Karyawan}

Mathis dan Jackson (2006) mendefinisikan Kinerja (performance), pada dasarnya adalah apa yang dilakukan atau tidak dilakukan oleh karyawan. Nawawi (1996) menyebutkan kinerja dengan istilah Karya yaitu adalah hasil pelaksanaan suatu pekerjaan baik bersifat fisik/material maupun non-fisik/nonmaterial. Hasibuan (2009) mengemukakan bahwa kinerja adalah suatu hasil kerja yang dicapai seorang dalam melaksanakan tugastugas yang dibebankan kepadanya yang didasarkan atas kecakapan, pengalaman dan kesungguhan serta waktu. Rivai dan Sagala (2009) menyatakan bahwa kinerja merupakan prilaku nyata yang ditampilkan setiap orang sebagai prestasi kerja yang dihasilkan oleh karyawan sesuai dengan perannya dalam perusahaan. Kinerja karyawan merupakan suatu hal yang sangat penting dalam upaya perusahaan untuk mencapai tujuannya.

Sulistiyani dan Rosidah (2009) mengemukakan penilaian kinerja meliputi beberapa dimensi kinerja yaitu : 1) kuantitas kerja, 2) kualitas kerja, 3) pengetahuan kerja, 4) kreativitas, 5) kerjasama, 6) kemandirian, 7) inisiatif, dan 8) kualitas individual. Sedangkan menurut Mitchel dan Larson (1987) dalam Riduwan dan Kuncoro (2011), mengemukakan tentang aspek-aspek kinerja meliputi : 1) kualitas hasil kerja, 2) kemampuan (capability), 3) prakarsa/inisiatif, 4) komunikasi, dan 5) ketepatan waktu. Mathis dan Jackson (2006) menyatakan kinerja karyawan yang umum meliputi elemen-elemen sebagai berikut : 1) kuantitas dari hasil, 2) kualitas dari hasil, 3) ketepatan waktu dari hasil, 4) kehadiran, dan 5) kemampuan bekerja sama.

\section{Kinerja Organisasi Pengelolaan Hutan Produksi secara Lestari (Kinerja PHPL)}

Pengelolaan Hutan Alam Produksi Lestari (PHAPL) adalah serangkaian strategi dan pelaksanaan kegiatan untuk menjamin keberlanjutan fungsi-fungsi produksi, ekologi dan sosial dari hutan alam produksi. Sedangkan Kinerja PHPL adalah nilai kuantitatif dan atau kualitatif pencapaian hasil pelaksanaan kegiatan pengelolaan hutan alam produksi pada suatu unit pengelolaan tertentu yang dicapai oleh Badan Usaha (SK Menteri Kehutanan Nomor 4796/Kpts-II/2002).

Peraturan yang secara spesifik mengatur tentang sistem sertifikasi pengelolaan hutan produksi lestari adalah Peraturan Menteri Kehutanan No. P.68/Menhut-II/2011 jo P.38/Menhut-II/2009 tentang "Standar dan Pedoman Penilaian Kinerja Pengelolaan Hutan Produksi Lestari dan Verifikasi Legalitas Kayu" dan Peraturan Direktorat Jenderal Bina Usaha Kehutanan Nomor P.8/VI-BPPHH/2011 tentang "Standar dan Pedoman Pelaksanaan Penilaian Kinerja Pengelolaan Hutan Produksi Lestari dan Verifikasi Legalitas Kayu”.

Selanjutnya Supriatna $d k k . \quad$ (2011) menyatakan Kinerja Pengelolaan Hutan secara Lestari (PHPL) secara garis besar terdiri dari 4 (empat) aspek/indikator, yaitu : 1) prasyarat, 2) produksi, 3) ekologi, dan 4) sosial.

\section{Tinjauan Studi Empirik}

Isu utama dalam penelitian ini adalah bahwa variabel investasi human capital, iklim organisasi akan berpengaruh terhadap kinerja karyawan dan dampaknya terhadap kinerja organisasi pengelolaan hutan produksi secara lestari (kinerja PHPL).

Keterbatasan studi terdahulu tersebut antara lain : 1) hasil penelusuran pada studi terdahulu di atas, variable investasi human capital sangat jarang diteliti. Variable yang banyak diteliti adalah Intellectual Capital (IC) dan Human Capital (HC), 2) belum ada variable iklim organisasi dalam penelitian terdahulu disandingkan dengan variable investasi human capital. Variable iklim organisasi banyak disandingkan dengan variable kepuasan kerja, motivasi dan komitmen, 3) locus penelitianpenelitian terdahulu belum pernah ada di perusahaan yang bergerak di sektor kehutanan, dan 4) belum pernah ada penelitian dengan 
Nandang Supriantna, Sugito Efendi dan Edi Sugiono, Pengaruh Investasi Human Capital Iklim..

variable kinerja organisasi dengan perspektif tujuan khusus PHPL.

Hasil-hasil penelitian terdahulu tersaji pada Tabel 2.1 di bawah ini :

\begin{tabular}{|c|c|c|c|c|}
\hline No. & Nama Peneliti (Tahun) & Judul Penelitian & Metodologi & Hasil Penelian \\
\hline 1. & $\begin{array}{l}\text { Bontis (1998); Bontis et. al. } \\
\text { (2000); Riahi dan Belkaoui } \\
\text { (2003); Astuti dan Sabeni } \\
\text { (2005); Chen et. al. (2005); } \\
\text { Tan et. al. (2007); Ulum } \\
\text { (2008); Ulum (2009); Guest } \\
\text { et. al. (2003); Nonaka dan } \\
\text { Takeuchi (1995); Zahra dan } \\
\text { George (2002); Nonaka dan } \\
\text { Takeuchi (1995); Black dan } \\
\text { Lynch (1996); Garcia (2005); } \\
\text { Khatri (2000) }\end{array}$ & $\begin{array}{l}\text { Penelitian-penelitian } \\
\text { yang terkait dengan } \\
\text { Intellectual Capital } \\
\text { (IC) yang terdiri dari } \\
\text { Human Capital (HC), } \\
\text { Structural Capital } \\
\text { (SC), dan Custumer } \\
\text { Capital (CC) }\end{array}$ & $\begin{array}{llr}\text { Partial } & \text { Least } & \text { Square } \\
(\text { PLS), } & \text { Regresi dan } \\
\text { korelasi, Value } & \text { Added } \\
\text { Intellectual } & \text { Capital } \\
\text { (VAIC) } & \end{array}$ & $\begin{array}{l}\text { Human Capital (HC), Structural } \\
\text { Capital (SC), dan Custumer Capital } \\
\text { (CC) baik secara parsial maupun } \\
\text { bersama-sama/simultan } \\
\text { berpengaruh signifikan terhadap } \\
\text { kinerja perusahaan }\end{array}$ \\
\hline 2. & Chamdani (2000) & $\begin{array}{l}\text { Analisis hubungan } \\
\text { Iklim perusahaan dan } \\
\text { Kepuasan Kerja }\end{array}$ & $\begin{array}{l}\text { Sebanyak } 125 \\
\text { responden dengan } \\
\text { random sampling } \\
\text { dengan metoda analisis } \\
\text { korelasi dari Parson }\end{array}$ & $\begin{array}{l}\text { Hasilnya adalah terdapat hubungan } \\
\text { signifikan antara kepuasan dengan } \\
\text { iklim perusahaan. }\end{array}$ \\
\hline 3. & Alugoro (2002) & $\begin{array}{l}\text { Analisis pengaruh } \\
\text { Iklim Kerja terhadap } \\
\text { Kepuasan Kerja }\end{array}$ & $\begin{array}{l}\text { Sebanyak } 177 \\
\text { responden yang } \\
\text { dianalisis, dengan teknis } \\
\text { pengambilan sampling } \\
\text { menggunakan } \\
\text { proportional purposive } \\
\text { non random sampling. }\end{array}$ & $\begin{array}{l}\text { Hasilnya adalah faktor iklim kerja } \\
\text { yang meliputi comformity, } \\
\text { responsibility, standard, reward, } \\
\text { clarity dan team spirit mempunyai } \\
\text { pengaruh positif yang signifikan } \\
\text { terhadap kepuasan kerja. }\end{array}$ \\
\hline 4. & Risetiawan (2002) & $\begin{array}{l}\text { Pengaruh iklim } \\
\text { organisasi dan } \\
\text { Motivasi terhadap } \\
\text { Kinerja Karyawan. }\end{array}$ & $\begin{array}{l}\text { Sebanyak } 75 \text { responden } \\
\text { yang diteliti dengan } \\
\text { analisis regresi. }\end{array}$ & $\begin{array}{l}\text { Hasilnya bahwa iklim organisasi } \\
\text { dan motivasi berpengaruh positif } \\
\text { dan signifikan terhadap kinerja } \\
\text { karyawan }\end{array}$ \\
\hline 5. & Affandi (2002) & $\begin{array}{l}\text { Pengaruh iklim } \\
\text { organisasi terhadap } \\
\text { komitmen, kepuasan } \\
\text { kerja dan kinerja } \\
\text { karyawan. }\end{array}$ & $\begin{array}{l}\text { Sebanyak } 135 \\
\text { responden yang diteliti } \\
\text { dengan metode } \\
\text { pengambilan sampling } \\
\text { Proportional purposif } \\
\text { non ramdom sampling }\end{array}$ & $\begin{array}{l}\text { Hasilnya bahwa iklim organisasi } \\
\text { yang meliputi structure, } \\
\text { responsibility, recognition and } \\
\text { reward, risk, warmth, support, } \\
\text { standard, conflict dan innovation, } \\
\text { mempunyai pengaruh positif dan } \\
\text { signifikan terhadap kepuasan kerja, } \\
\text { komitmen dan kinerja pegawai }\end{array}$ \\
\hline 6. & Widyastuti (2004) & $\begin{array}{l}\text { Pengaruh iklim } \\
\text { organisasi dan } \\
\text { motivasi terhadap } \\
\text { kinerja. }\end{array}$ & $\begin{array}{l}\text { Responden sebanyak } \\
117 \text { dengang } \\
\text { menggunakan metode } \\
\text { SEM }\end{array}$ & $\begin{array}{l}\text { Hasilnya adalah iklim organisasi } \\
\text { dan motivasi berpengaruh positif } \\
\text { terhadap kinerja }\end{array}$ \\
\hline
\end{tabular}

\section{METODOLOGI}

Kerangka Pikir Penelitian diuraikan sebagai berikut bahwa peranan human capital di perusahaan PT. Kalimantan Satya Kencana (PT.KSK) sangat penting karena mempengaruhi organisasi secara keseluruhan (Bontis et.al., 1999 dalam Hutapea dan Thoha, 2008). Pengembangan human capital adalah sebuah bentuk investasi dan merupakan tuntutan dari perekonomian modern yang tidak bisa dihindari. Investasi Human Capital merupakan suatu upaya untuk meningkatkan nilai tambah "barang atau jasa" yang dihasilkan di kemudian hari dengan mengorbankan kesempatan untuk menikmati konsumsi hari ini. Sesuai prinsip investasi manusia, nilai ekonomisnya dapat berkembang di kemudian hari melalui suatu proses pertambahan nilai seperti peningkatan sikap, perilaku, wawasan, kemampuan, keahlian dan keterampilan (Muhi, 2012). Dengan peningkatan sikap, perilaku, wawasan, kemampuan, keahlian dan keterampilan karyawan, maka akan berpengaruh terhadap kinerja karyawan yang pada akhirnya akan mempengaruhi kinerja organisasi.

Iklim organisasi sebagai suatu sistem 
sosial, sangat dipengaruhi oleh lingkungan baik internal maupun eksternal. Perpaduan lingkungan internal dan eksternal tersebut, akan mempengaruhi aktifitas, norma, sikap dan peran yang pada akhirnya akan mempengaruhi produktivitas, kepuasan kerja dan kinerja serta pertumbuhan organisasi (Sujak, 1990). Wirawan (2007) memberikan definisi iklim organisasi yang lebih luas yaitu persepsi anggota organisasi (secara individu dan kelompok) dan mereka yang secara tetap berhubungan dengan organisasi (misalnya pemasok, konsumen, konsultan, dan kontraktor) mengenai apa yang ada atau terjadi di lingkungan internal organisasi secara rutin, yang mempengaruhi sikap dan perilaku organisasi dan kinerja anggota organisasi yang kemudian menentukan kinerja organisasi.

Berdasarkan kerangka pikir penelitian diatas, maka dapat disampaikan kerangka model seperti pada Gambar 3.1 di bawah ini.

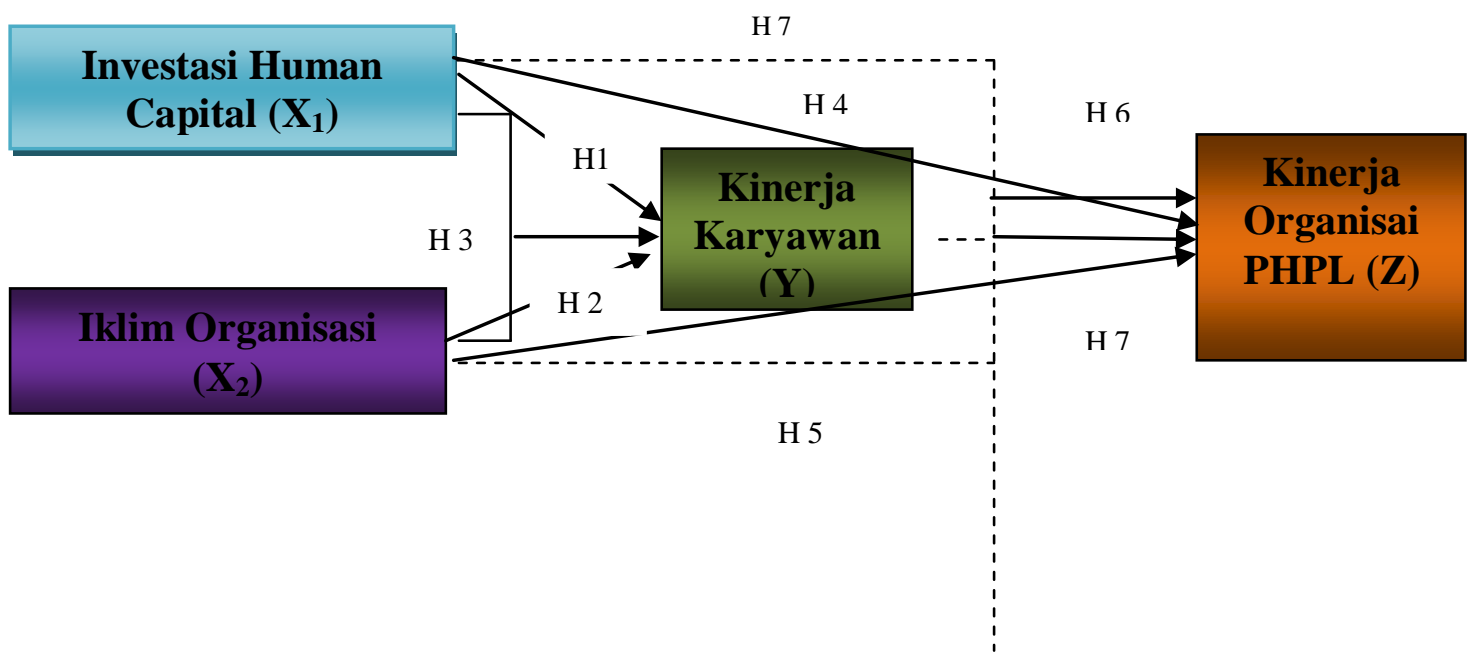

Gambar 3.1. Kerangka Model Diagram Alur Antara Investasi Human Capital $\left(\mathrm{X}_{1}\right), \quad$ Iklim Organisasi $\left(\mathrm{X}_{2}\right)$, Kinerja Karyawan (Y) Dan Kinerja Organisasi (Z) Sumber : Riduwan dan Kuncoro (2011); Sandjojo (2011); Ferdinand (2006)

Atas dasar kerangka pikir dan kerangka model tersebut maka dapat ditarik hipotesis dengan menggunakan metode berpikir Silogisme yaitu suatu proses penarikan kesimpulan secara deduktif. Berpikir deduktif adalah suatu cara berpikir di mana dari pernyataan yang bersifat umum ditarik kesimpulan yang bersifat khusus.

Hipotesis 1 :

Investasi Human Capital signifikan dan positif terhadap kinerja karyawan PT. Kalimantan Satya Kencana.

\section{Hipotesis 2 :}

Iklim Organisasi berpengaruh signifikan dan positif terhadap kinerja karyawan PT. Kalimantan Satya Kencana.

\section{Hipotesis 3 :}

Investasi Human Capital dan Iklim Organisasi berpengaruh signifikan dan positif terhadap kinerja karyawan PT. Kalimantan Satya Kencana secara bersama-sama.

\section{Hipotesis 4 :}

Investasi Human Capital berpengaruh signifikan dan positif terhadap kinerja organisasi Pengelolaan Hutan Produksi secara Lestari (Kinerja PHPL) PT. Kalimantan Satya Kencana.

\section{Hipotesis 5 :}

Iklim Organisasi berpengaruh signifikan dan positif terhadap kinerja organisasi Pengelolaan Hutan Produksi secara Lestari (Kinerja PHPL) PT. Kalimantan Satya Kencana.

\section{Hipotesis 6 :}

Kinerja karyawan berpengaruh signifikan dan positif terhadap kinerja organisasi Pengelolaan 
Nandang Supriantna, Sugito Efendi dan Edi Sugiono, Pengaruh Investasi Human Capital Iklim..

Hutan Produksi secara Lestari (Kinerja PHPL) PT. Kalimantan Satya Kencana.

\section{Hipotesis 7 :}

Investasi Human Capital, Iklim Organisasi dan Kinerja Karyawan berpengaruh signifikan dan positif terhadap kinerja organisasi Pengelolaan Hutan Produksi secara Lestari (Kinerja PHPL) PT. Kalimantan Satya Kencana secara bersamasama/simultan.

Sesuai dengan tujuan penelitian, maka desain penelitian yang digunakan adalah Kausaliltas. Jenis dan Sumber Data adalah berupa Data primer, berupa pengisian kuesioner dan data skunder perusahaan yang diteliti.

Metoda pengambilan sampel yang digunakan adalah "Probability Sampling", dengan teknis pengambilan sampel dengan cara Acak Sederhana (Simple Random Sampling). Jumlah sampel ditentukan dengan menggunakan Rumus Slovin (Umar, 2010), diperoleh sebanyak 58 orang.

Proses pengukuran dilakukan pada instrumennya berupa kuisioner/pertanyaanpertanyaan. Kemudian untuk bisa diukur variabel-variabel penelitian harus didefinisikan secara operasional (Tabel 3-1). Skala pengukuran menggunakan Skala Sikap Likert. Data yang diperoleh melalui kuesioner mempunyai skala ordinal, dalam pengerjaannya data tersebut ditransformasikan menjadi skala interval dengan menggunakan Method of Successive Interval (MSI).

Untuk memastikan bahwa instrumen dapat dianggap sah (valid) dan dipercaya serta reliabel (konsisten dan ajeg), maka dilakukan uji validitas dan uji relibilitas. Terhadap variabel yang tidak valid, maka tidak disertakan dalam analisis selanjutnya.

Tabel 3.1. Operasionalisasi Definisi Variabel

\begin{tabular}{|c|c|c|}
\hline Variabel & Definisi Operasional & Indikator \\
\hline $\begin{array}{l}\text { Investasi } \\
\text { Human } \\
\text { Capital } \\
\text { (X1) }\end{array}$ & $\begin{array}{l}\text { Upaya-upaya yang dilakukan untuk } \\
\text { meningkatkan nilai tambah karyawan } \\
\text { yang dihasilkan di kemudian hari. }\end{array}$ & $\begin{array}{l}\text { 1) Pendidikan dan pelatihan, } \\
\text { 2) On the job training, } \\
\text { 3) Tingkat dan latar belakang pendidikan } \\
\text { 4) Pengalaman kerja } \\
\text { (Becker, } 1975 \text { dan Unger, et. al., } 2009 \text { dalam Tjiptono, } \\
\text { 2011) }\end{array}$ \\
\hline $\begin{array}{l}\text { Iklim } \\
\text { Organisas } \\
\text { i (X2) }\end{array}$ & $\begin{array}{l}\text { Persepsi karyawan mengenai apa yang } \\
\text { ada atau terjadi di lingkungan internal } \\
\text { organisasi secara rutin, yang } \\
\text { mempengaruhi kinerja karyawan yang } \\
\text { kemudian menentukan kinerja organisasi. } \\
\text { lingkungan organisasi. }\end{array}$ & $\begin{array}{l}\text { 1) Struktur } \\
\text { 2) Standar-standar } \\
\text { 3) Tanggung jawab } \\
\text { 4) Penghargaan/pengakuan } \\
\text { 5) Dukungan, dan } \\
\text { 6) Komitmen } \\
\text { (Stringer, 2002 dalam Wirawan, 2007) }\end{array}$ \\
\hline $\begin{array}{l}\text { Kinerja } \\
\text { Karyawan } \\
(\mathrm{Y})\end{array}$ & $\begin{array}{l}\text { hasil kerja yang dicapai seorang } \\
\text { karyawan dalam melaksanakan tugas- } \\
\text { tugas yang dibebankan kepadanya. }\end{array}$ & $\begin{array}{l}\text { 1) Kualitas hasil kerja } \\
\text { 2) Kuantitas hasil kerja } \\
\text { 3) Ketepatan waktu } \\
\text { 4) Pengetahuan kerja } \\
\text { 5) Kreativitas } \\
\text { 6) Prakarsa/inisiatif } \\
\text { 7) Komunikasi } \\
\text { 8) Kehadiran } \\
\text { 9) Kemampuan bekerja sama } \\
\text { (Sulistiyani dan Rosidah, 2009; Mathis dan Jackson, 2006; } \\
\quad \text { Mitchel dan Larson, 1987) }\end{array}$ \\
\hline $\begin{array}{l}\text { Kinerja } \\
\text { Organisas } \\
\text { i PHPL } \\
\text { (Z) }\end{array}$ & $\begin{array}{l}\text { Nilai pencapaian hasil dari perspektif } \\
\text { pelaksanaan kegiatan pengelolaan hutan } \\
\text { alam produksi lestari pada perusahaan } \\
\text { Izin Usaha Pemanfaatan Hasil Hutan } \\
\text { Kayu dalam Hutan Alam (IUPHHK-HA) }\end{array}$ & $\begin{array}{l}\text { 1) Prasyarat } \\
\text { 2) Produksi } \\
\text { 3) Ekologi } \\
\text { 4) Sosial } \\
\text { (Peraturan Menteri Kehutanan No. P.68/Menhut-II/2011 } \\
\text { jo P.38/Menhut-II/2009 dan Peraturan Dirjen Bina Usaha } \\
\text { Kehutanan, Kemhut Nomor P.8/VI-BPPHH/2011) }\end{array}$ \\
\hline
\end{tabular}


Metoda analisis menggunakan Analisis Jalur (Path Analysis) dengan gambar diagramatik struktur hubungan kausal antara variabel seperti Gambar 3.2. pada halaman berikut. Untuk menguji koefisien jalur pada masing-masing hubungan kasualitas, 7 (tujuh) hipotesis penelitian dalam bentuk kalimat harus diterjemahkan lebih dahulu ke dalam hipotesis statistik sebagai berikut :

\begin{tabular}{|c|c|c|c|}
\hline $\begin{array}{l}\text { Hipotesis } 1: \\
\mathrm{H}_{1}: p y x 1 \neq 0 \\
\text { Ho:pyx } 1=0\end{array}$ & $\begin{array}{l}\text { Hipotesis 2: } \\
\mathrm{H}_{1}: \rho y \times 2 \neq 0 \\
\mathrm{Ho}_{\mathrm{O}} \mathrm{\rho y} \mathrm{x} 2=0\end{array}$ & $\begin{array}{l}\text { Hipotesis 3: } \\
\mathrm{H}_{1}: \rho y x 1=\rho y \times 2 \neq 0 \\
\mathrm{Ho}: \rho y x 1=\rho y \times 2=0\end{array}$ & $\begin{array}{l}\text { Hipotesis } 4: \\
\mathrm{H}_{1}: \rho z x 1 \neq 0 \\
\mathrm{Ho}: \rho z \times 1=0\end{array}$ \\
\hline $\begin{array}{l}\text { Hipotesis 5: } \\
\mathrm{H}_{1}: \rho z \times 2 \neq 0 \\
\mathrm{Ho}: \rho z \times 2=0\end{array}$ & $\begin{array}{l}\text { Hipotesis 6: } \\
\mathrm{H}_{1}: p z y \neq 0 \\
\mathrm{Ho}_{\mathrm{p}} \mathrm{pz}=0\end{array}$ & $\begin{array}{l}\text { Hipotesis 7: } \\
\mathrm{H}_{1}: \rho z x 1=\rho z x 2=\rho z y \neq 0 \\
\mathrm{Ho}: \rho z x 1=\rho z x 2=\rho z y=0\end{array}$ & \\
\hline
\end{tabular}

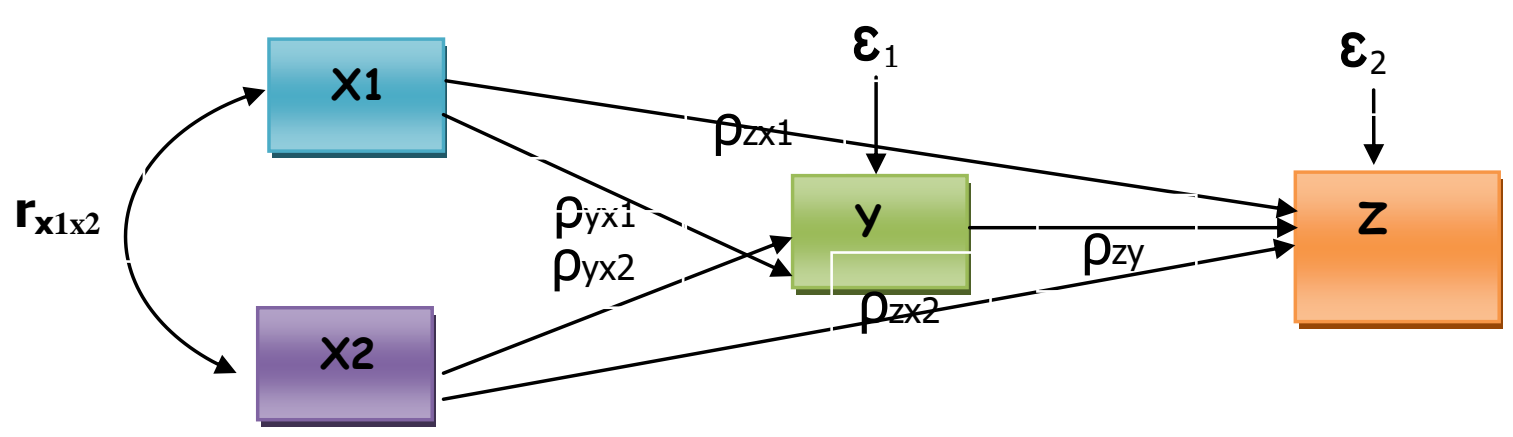

Gambar 3.2. Diagram Jalur Hubungan Kausal X1, X2, dan Y ke Z

Model hubungan kausal dalam persamaan struktural :

$$
\begin{aligned}
& Y=\rho_{y x 1} X_{1}+\rho_{y \times 2} X_{2}+\varepsilon_{1} \\
& Z=\rho_{z x 1} X_{1}+\rho_{z x 2} X_{2}+\rho_{z y} Y+\varepsilon_{2}
\end{aligned}
$$

Untuk melakukan uji hipotesis pengaruh variabel penyebab terhadap variabel akibat secara parsial digunakan statistik uji $t$ student, sedangkan pengaruh variabel penyebab terhadap variabel akibat secara bersamasama/simultan digunakan statistik uji $F$.
Uji Asumsi Klasik yang dilakukan adalah : 1) Uji Normalitas, 2) Uji Multikolinearitas, dan 3) Uji Heteroskedastitas.

HASIL DAN PEMBAHASAN 
Nandang Supriantna, Sugito Efendi dan Edi Sugiono, Pengaruh Investasi Human Capital Iklim..

Profil responden adalah sebagai berikut : a). Jenis kelamin didominasi laki-laki yaitu berjumlah 45 orang $(77,6 \%)$ dan sisanya wanita berjumlah 13 orang $(22,4 \%)$; b). Tingkat berpendidikan terdiri dari SMA sebanyak 30 orang $(51,7 \%)$, Sarjana/S1 sebanyak 21 orang $(36,2 \%)$, S2/Magister sebanyak 4 orang $(6,9$ $\%)$, dan SMP sebanyak 3 orang (5,2 \%). Hampir semua responden melek huruf; c). Masa kerja tertinggi dengan masa kerja 1 - 5 tahun sebanyak 41 orang $(70,7 \%)$, jumlah terkecil dengan masa kerja di bawah 1 tahun sebanyak 10 orang $(17,2 \%)$ dan masa kerja di atas 5 tahun sebanyak 7 orang (12,1\%); d). Jabatan didominasi oleh tingkat staf sebanyak 35 orang $(60,3 \%)$, disusul tingkat supervisor sebanyak 16 orang $(27,6 \%)$ dan tingkat manajer sebanyak 7 orang $(12,1 \%)$.

Hasil uji realibilitas dan validitas data instrumen adalah : a) Keseluruhan instrumen adalah handal/reliable, karena nilai Alpha Cronbachnya diatas 0,6 (Nurgiyantoro dalam Apriyanto, 2008); b). Pada variabel investasi human capital (X1) terdapat 2 butir pertanyaan yang tidak valid, pada variabel iklim organisasi (X2) semua butir pertanyaan valid, pada variabel kinerja karyawan (Y) terdapat 1 butir pertanyaan yang tidak valid, dan pada variabel kinerja PHPL (Z) terdapat 3 butir pertanyaan yang tidak valid. Pada butir-butir pertanyaan yang tidak valid tersebut, maka tidak disertakan (dikeluarkan) dari analisis selanjutnya.

Hasil Uji Klasik menunjukan memenuhi persyaratan-persyaratan model persamaan regresi yaitu terdistribusi normal, tidak terjadi heteroskedastisitas dan tidak terjadi mulitikolineritas.

Hasil perhitungan analisis jalur adalah sebagai berikut : a). Secara signifikan dan searah (positif) Investasi Human Capital berpengaruh langsung terhadap kinerja karyawan PT. Kalimantan Satya Kencana. Konstribusi atau sumbangan investasi human capital sebesar $12,18 \%$ dapat menjelaskan Kinerja Karyawan, sisanya sebesar $87,82 \%$ dipengaruhi oleh faktor lainnya; b). Secara signifikan dan searah (positif) Iklim Organisasi berpengaruh langsung terhadap kinerja karyawan PT. Kalimantan Satya Kencana. Konstribusi pengaruh iklim organisasi terhadap Kinerja perusahaan sebesar $6,15 \%$, sisanya sebesar $93,85 \%$ dipengaruhi faktor-faktor lain; c). Secara signifikan dan simultan investasi human capital dan iklim organisasi berpengaruh searah (positif) terhadap kinerja karyawan sebesar 17,6\% artinya varian kinerja karyawan dapat dijelaskan dengan varian investasi human capital dan iklim organisasi sebesar $17,6 \%$ dan sisanya sebesar $82,4 \%$ dipengaruhi oleh faktor-faktor lain; d). Investasi Human Capital tidak berpengaruh langsung secara signifikan terhadap Kinerja Pengelolaan Hutan secara Lestari (PHPL) PT. KSK. Akan tetapi secara tidak langsung berpengaruh melalui variable kinerja karyawan dengan total konstribusi pengaruh sebesar 10,61 $\%$; e). Iklim organisasi berpengaruh langsung secara signifikan dan searah (positif) terhadap Kinerja Pengelolaan Hutan secara Lestari (PHPL) PT. KSK dengan konstribusi sebesar $16,89 \%$ dan sisanya sebesar $83,11 \%$ pengaruh dari faktor-faktor lainnya. Selain berpengaruh secara langsung, iklim organisasi berpengaruh secara tidak langsung melalui kinerja karyawan terhadap kinerja PHPL dengan konstribusi sebesar 7,54 \%; g). Kinerja karyawan secara signifikan berpengaruh langsung dan searah (positif) terhadap Kinerja PHPL dengan konstribusi sebesar 9,24\%, dan sisanya sebesar 90,76\% akibat faktor-faktor lainnya; h). Hasil metode analisis jalur trimming diperoleh bahwa iklim organisasi dan kinerja karyawan berkonstribusi secara simultan dan signifikan serta searah (positif) terhadap kinerja PHPL dengan besar konstribusi adalah sebagai berikut: 1) besarnya konstribusi iklim organisasi yang secara langsung mempengaruhi kinerja PHPL adalah 16,89\%, sedangkan secara tidak langsung melalui kinerja karyawan sebesar $7,54 \%$, 2) besarnya konstribusi kinerja karyawan yang secara langsung mempengaruhi kinerja PHPL adalah 9,24\%, 3) besarnya konstribusi iklim organisasi dan kinerja karyawan yang secara simultan dan langsung mempengaruhi kinerja PHPL adalah 31,9\%, sisanya sebesar $68,1 \%$ dipengaruhi oleh faktorfaktor lain; i). Besarnya konstribusi pengaruh total langsung dan tidak langsung model struktur akhir dengan metode trimming menyebabkan adanya lintasan signifikan yang memberikan arah perubahan pada jalur yang harus dilewati dari hubungan kausalitas. Signifikansi melalui lintasan penelusuran faktor-faktor penyebab meningkatnya Kinerja 
PHPL melalui intervening Kinerja Karyawan oleh Investasi Human Capital dan Iklim Organisasi secara proporsional adalah menjadi $44,28 \%$.

Diagram jalur akhir (metode trimming) keseluruhan hubungan kausal empiris antara variabel Investasi Human Capital (X1), Iklim Organisasi (X2), Kinerja Karyawan (Y) dan Kinerja PHPL (Z) sebagaimana tersaji pada Gambar di bawah berikut :

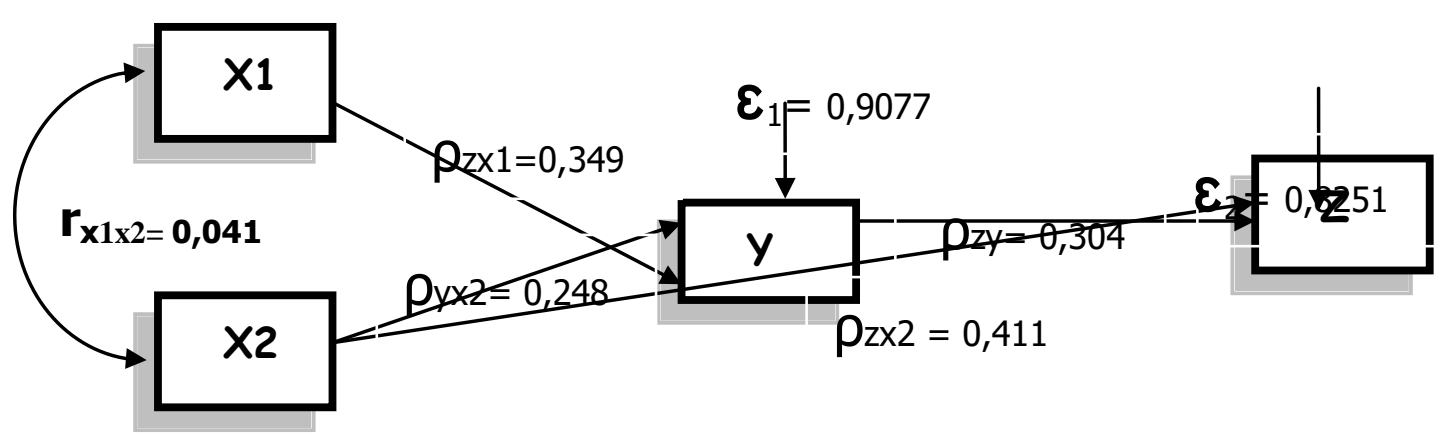

Persamaan Struktural Akhir, yaitu sebagai berikut :

$$
\begin{aligned}
& Y=0,349 X_{1}+0,248 X_{2}+0,9077 \varepsilon_{1} ; R^{2} \mathbf{y} \times 1 \times 2=0,176 \\
& Z=0,411 X_{2}+0,304 Y+0,8251 \varepsilon_{2} ; R^{2} \mathrm{zyx}=0,319
\end{aligned}
$$

Hasil temuan penelitian ini terbukti secara faktual di lapangan yaitu dari hasil penilaian kinerja PHPL oleh Lembaga Penilai Indenpenden (LPI) PT. Mutu Agung Lestari dengan hasil bahwa PT. KSK dinyatakan lulus dengan predikat BAIK dan memperoleh sertifikat PHPL dengan nomor LPPHPL008/MUTU/FM-005 tanggal 6 November 2012.

\section{KESIMPULAN}

Berdasarkan hasil pembuktian hipotesis melalui prosedur penelitian yang telah dilakukan, maka dapat disimpulkan antara lain : 1). Secara signifikan dan searah (positif) Investasi Human Capital berpengaruh langsung terhadap kinerja karyawan PT. Kalimantan Satya Kencana; 2). Secara signifikan dan searah (positif) Iklim Organisasi berpengaruh langsung terhadap kinerja karyawan PT. Kalimantan Satya Kencana; 3). Secara signifikan dan simultan investasi human capital dan iklim organisasi berpengaruh searah (positif) terhadap kinerja karyawan; 4). Investasi Human Capital tidak berpengaruh langsung secara signifikan terhadap Kinerja Pengelolaan Hutan secara Lestari (PHPL) PT. KSK. Akan tetapi secara tidak langsung berpengaruh melalui variable kinerja karyawan; 5). Iklim organisasi berpengaruh langsung secara signifikan dan searah (positif) terhadap Kinerja Pengelolaan
Hutan secara Lestari (PHPL) PT; 6). Kinerja karyawan secara signifikan berpengaruh langsung dan searah (positif) terhadap Kinerja PHPL; 7). Hasil metode analisis jalur trimming diperoleh bahwa hanya iklim organisasi dan kinerja karyawan berkonstribusi secara simultan dan signifikan serta searah (positif) terhadap kinerja PHPL, sedangkan Investasi Human Capital berpengaruh tidak langsung melalui Kinerja Karyawan di PT. Kalimantan Satya Kencana (PT.KSK)

\section{SARAN}

Berdasarkan kesimpulan diatas beberapa saran yang dapat peneliti sampaikan antara lain : 1). Terkait dengan Investasi Human Capital yang tidak mempengaruhi secara signifikan dan langsung terhadap Kinerja PHPL, maka yang harus dilakukan untuk meningkatkan nilai tambah karyawan antara lain : a) Mengikutsertakan karyawan dalam pendidikan dan pelatihan (diklat) sesuai dengan keahliannya dan kebutuhan, b) Transfer pengetahuan dari yang ahli dan pengalaman kepada karyawankaryawan lainnya atau bawahan dalam pelaksanaan kerja harian harus dijadikan suatu prosedur standar, dan c) Bagian HRD harus melakukan analisa jabatan (job analysis) terkait dengan perekrutan dan penempatan karyawan 
Nandang Supriantna, Sugito Efendi dan Edi Sugiono, Pengaruh Investasi Human Capital Iklim..

yang disesuaikan dengan tingkat dan latar belakang pendidikan serta pengalaman Kerja.

Mengingat nilai konstribusi secara keseluruhan masih relatif kecil yaitu 44,28 \%, sedangkan sisanya masih sebesar $55,72 \%$ yang merupakan factor-faktor lain yang tidak termasuk variable yang diteliti, maka disarankan kepada penelitian yang akan datang untuk mencoba meneliti dengan variable lain yang berpengaruh terhadap kinerja PHPL seperti variable kepemimpinan, komitmen, kompetensi, kompensasi, budaya organisasi dan lain-lain.

\section{DAFTAR PUSTAKA}

Anatan, L. dan L. Ellitan, 2009, Manajemen Sumber Daya Manusia dalam Bisnis Modern, Cetakan Kedua, Penerbit Alfabeta, Bandung.

Anonim, 2011, Peraturan Direktur Jenderal Bina Usaha Kehutanan Nomor : P.8/VIBPPHH/2011 tentang Standard dan Pedoman Pelaksanaan Penilaian Kinerja Pengelolaan Hutan Produksi Lestari (PHPL) dan Verifikasi Legalitas Kayu (VLK), Direktorat Jenderal Bina Usaha Kehutanan Kementerian Kehutanan, Jakarta.

Anonim, 2011, Peraturan Menteri Kehutanan Nomor P.68/Menhut-II/2011 tentang Perubahan atas Peraturan Menteri Kehutanan Nomor P.38/Menhut-II/2009 tentang Standard dan Pedoman Pelaksanaan Penilaian Kinerja Pengelolaan Hutan Produksi Lestari (PHPL) dan Verifikasi Legalitas Kayu (VLK) pada Pemegang Izin atau pada Hutan Hak, Kementerian Kehutanan Republik Indonesia, Jakarta.

Apriyatno, H., 2008, Pengaruh Iklim Organisasi Terhadap Komitmen dan Kepuasan Kerja serta Implikasinya Pada Prestasi Kerja (Studi pada PT. PLN (Persero) UP Dinoyo Malang), Program Pasca Sarjana STIEKN Jaya Negara Malang.

Atmanti, H. D., 2005, Investasi Sumber Daya Manusia, Dinamika Pembangunan, 2 (1) : 30 - 39. Juli 2005.

Becker, G. S., 1962, Invesment In Human Capital : A Theoretical Analysis,
The Journal of Political Economy, 70 (5) : 9 - 49, October 1962.

Bontis, N., 1998, Intellectual Capital : An Exploratory Study that Develops Measures and Models, Journal Management Decision, 30 (2) : 63 76, 1998.

Cornachione, E. B., 2010, Investing In Human Capital : Integrating Intellectual Capital Arthitecture and Utility Theory, The Journal of Human Resource and Adult Learning, 6 (1) : 29 - 40, June 2010.

Endri, 2010, Peran Human Capital Dalam Meningkatkan Kinerja Perusahaan : Suatu Tinjauan Teoritis dan Empiris, Jurnal Administrasi Bisnis, $6(2): 179-190,2010$.

Ferdinand, A., 2006, Metode Penelitian Manajemen : Pedoman Penelitian Untuk Penulisan Skripsi, Tesis dan Desertasi Ilmu Manajemen, Edisi 2, Badan Penerbit Universitas Dipenogoro, Semarang.

Hendrawan, S., Indraswari, S. Yazid, 2012, Pengembangan Human Capital : Perspektif Nasional Regional dan Global, Cetakan Pertama, Graha Ilmu, Yogyakarta.

Hutapea, P. dan N. Thoha, 2008, Kompetensi Plus : Teori Desain Kasus dan Penerapan untuk HR dan Organisasi yang Dinamis, Gramedia Pustaka Utama, Jakarta.

Mathis, R. L. and J. H. Jackson, 2006, Human Resource Mangement, Edisi 10, Penerbit Salemba Empat, Jakarta.

Moeheriono, 2012, Perencanaan Aplikasi dan Pengembangan Indikator Kinerja Utama (IKU) Bisnis dan Publik, Cetakan Pertama, Rajawali Pers, Jakarta.

Muhi, A. H., 2012, Analisis Investasi Modal Manusia Dalam Perspektif Pendidikan dan Pelatihan, http//:alimuhi.staa.ipdn.ac.id, 5/4/2012.

Nawawi, H., 2000, Manajemen Sumber Daya Manusia untuk Bisnis yang Kompetitif, Cetakan Ketiga, Gajah Mada University Press, Yogyakarta. 
Nazari, J. A. et al., 2011, Organizational Culture, Climate and Intellectual Capital : An Interaction Analysis, Journal of Intellectual Capital Emerald, 12 (2) : 224 - 248, 2011.

Ngadiono, 2004, 35 Tahun Pengelolaan Hutan Indonesia : Refleksi dan Prospek, Cetakan Pertama, Yayasan Adi Sanggoro, Bogor.

Oei, I., 2010, Riset Sumber Daya Manusia, Cetakan Kelima, PT Gramedia Pustaka Utama, Jakarta.

Olaniyan, D. A. and Okemakinde, 2008, Human Capital Theory : Implications for Educational Development, European Journal of Scientific Research, 24 (2) : 157 - 162, 2008.

Riduwan dan E. A. Kuncoro, 2011, Cara Menggunakan dan Memaknai Path Analysis (Analisis Jalur), Cetakan Ketiga, Penerbit Alfabeta, Bandung.

Rivai, A. F. M., M. S. M. Yasin dan B. Abdullah, 2009, Manajemen Sumber Daya Manusia untuk Perusahaan : Dari Teori ke Praktek, Edisi Kedua, Rajawali Pers, Jakarta.

Sandjojo, N., 2011, Metode Analisis Jalur (Path Analysis) dan Aplikasinya, Cetakan Pertama, Pustaka Sinar Harapan, Jakarta.

Simanjuntak, P. Y., 1998, Pengantar Ekonomi Sumber Daya Manusia, Edisi Kedua, Lembaga Penerbit Fakultas Ekonomi Universitas Indonesia, Jakarta.

Sudjana, N., 1991, Tuntunan Penyusunan Karya Ilmiah : Makalah-Skripsi-TesisDesertasi, Cetakan kedua, Penerbit CV. Sinar Baru, Bandung.

Sugiyono, 2009, Metode Penelitian Kuantitatif Kualitatif dan R \& D, Cetakan ke-6, CV. Alfabeta, Bandung.

Sujak, A., 1990. Kepemimpinan Manajer Eksistensinya dalam Prilaku Organisasi. Radar Jaya, Jakarta.

Sulistiyani, A. T. dan Rosidah, 2009, Manajemen Sumber Daya Manusia : Konsep Teori dan Pengembangan dalam Konteks Organisasi Publik, Cetakan Pertama, Graha Ilmu, Yogyakarta.
Supriatna, N. dkk., 2011, Buku Pedoman Pengurusan Perizinan dan Pelaksanaan Usaha Pemanfaatan Hasil Hutan Kayu (UPHHK) Secara Lestari : Berdasarkan Peraturan Perundang-Undangan di Indonesia, Asosiasi Pengusaha Hutan Indonesia (APHI), Jakarta.

Ulum, I., 2009, Intellectual Capital : Konsep dan Kajian Empiris, Cetakan Pertama, Graha Ilmu, Yogyakarta.

Umar, H., 2010, Desain Penelitian MSDM dan Perilaku Karyawan : Paradigma Positivistik dan Berbasis Pemecahan Masalah, Cetakan ke-3, Rajawali Pers, Jakarta. 